\title{
The Identification of Chemical and Bacterial Composition and Determination of FimH Gene Frequency of Kidney Stones of Iranian Patients
}

\author{
Ali Shojaeian, ${ }^{1,{ }^{*}}$ Mosayeb Rostamian, ${ }^{2}$ Jamileh Noroozi, ${ }^{1}$ and Parviz Pakzad ${ }^{1}$ \\ ${ }^{1}$ Department of Microbiology, Faculty of Basic Sciences, Tehran North Branch, Islamic Azad University, Tehran, IR Iran \\ ${ }^{2}$ Department of Immunology, Pasteur Institute of Iran, Tehran, IR Iran \\ "Corresponding author: Ali Shojaeian, Department of Microbiology, Faculty of Basic Sciences, Tehran North Branch, Islamic Azad University, Tehran, IR Iran. E-mail: \\ ali.sh1390@yahoo.com
}

Received 2015 January 26; Accepted 2015 July 10.

\begin{abstract}
Background: There is rare study on the association between FimH and kidney stone formation in our country.

objectives: Here we studied on stones and identified the bacteria in stones isolated from kidney stone disease and/or UTI patients attending to Hashemi-Nejad hospital (Tehran, Iran) to find out a possible correlation between stone composition and the diseases. We also measure the frequency of fimH gene and its related protein in Escherichia coli isolated from the patients to clarify the effect of this gene in kidney stone formation.

Patients and Methods: In This observational-descriptive study, 40 kidney stone samples were gathered and the composition of each sample was determined. The frequency of fimH gene and its related protein was measured using PCR and protein extraction from separated E. coli bacteria.

Results: The most prevalence of stones belonged to calcium oxalate stones and the most frequent bacterium in kidney stones was E. coli. The frequency of fimH gene in isolated E. coli was 57.14\%.

Conclusions: Our data indicated that almost all chemical types of kidney stones may involve in UTI and kidney stone formation. We also realized that although $E$. coli is a non-urea splitting bacteria, it is the most causative microorganism found in urine and stones. Finally we recognized that fimH gene is seen in the majority of kidney stone samples so it may have a role in formation of kidney stone, although it should be more clarified in future studies.
\end{abstract}

Keywords: Chemical Composition, Kidney Stone, Urinary Tract Infections, Iran

\section{Background}

Kidney stone disease (or nephrolithiasis) is relatively common, with a lifetime risk of approximately $5 \%$ for both genders. A possible environmental cause as well as genetic predisposition is responsible for the increasing of kidney stone prevalence among both sexes of all ages [1]. During the last decades, a lot of studies have been done on the physical chemistry of stones formation. It is well known that crystallization processes alone cannot be able to explain the pathophysiology of kidney stone disease [2]. Five types of crystalline components in urinary tract stones have been reported: calcium oxalate, calcium phosphate, bacterial related, purine and cystine. A mixture of two or more of these components covers the majority of urinary stones. The most common component of kidney stones is calcium oxalate combined with apatite [3]. One of the most frequent infections in developed countries is UTIs (Urinary tract infections). uropathogenic Escherichia coli (E. coli), a non-urea-splitting bacterium, represent $80 \%$ of uncompli- cated UTIs. Increasing of the fitness of bacteria causing UTIs during infection is highly associated with their virulence factors [4]. Some of E. coli virulence factors are adhesins (Type 1 pili, $P$ fimbriae, Dr-family pili, S fimbriae, F1C fimbriae) and toxins Cytotoxic Necrotizing Factor- 1 and Secreted autotransporter toxin (CNF1 and Sat) [5]. FimH is a member of $E$. coli fimbriae family, which participate in bacterial adhesion [6] and has a role in diseases related to bacterial autoaggregation such as UTI $[7,8]$.

Urinary tract infections are associated with kidney stone formation [9]. Furthermore, antimicrobial resistance has been frequently reported in bacteria separated from stone formers with UTIs [10].

Perviously, several studies have shown that the most prevalence of bacteria associated with UTI is E. coli [11], and oxalate calcium is the most frequent component of kidney stones [11]. Also some studies have indicated the relation of FimH gene and UTI [12]. Although the association between kidney stone disease and UTIs is frequently observed, more studies should be done on its prevalence, 
antimicrobial susceptibility pattern and its causative microorganisms [13]. Also there is rare study on the association between FimH and kidney stone formation in our country.

\section{Objectives}

Therefore, the purpose of this research was to study on stones and identify the bacteria in patients' kidney stones attending to Hashemi-Nejad hospital (Tehran, Iran). We also measure the frequency of fimH gene and its related protein in E. coli isolated from the patients to find out the effect of this protein in kidney stone formation.

\section{Patients and Methods}

\subsection{Samples}

In this observational-descriptive study, 40 kidney stone samples were gathered from Shahid HashemiNejad hospital by PCNL (percutaneous nephrolithotomy) method. A piece of each sample was used for culturing of kidney stone bacteria and the remained amount was applied for further analysis. All patients gave written informed consent.

\subsection{Kidney Stone Analysis}

The composition of each sample was determined using a kidney stone determination kit (IranKav, Iran). The kit contains all necessary reagents for semi-quantitative measurement of the most important components of kidney stones including calcium, oxalate, magnesium, phosphate, ammonium, uric acid and cystine. Initially a homogenous powder was prepared from each sample and dissolved by adding some pure sulfuric acid and the final volume was adjusted to $50 \mathrm{~mL}$ using distilled water. The prepared samples were used for determination of different parameters using the mentioned kit.

\subsection{Kidney Stones Culture}

In order to analysis the bacterial component of each sample, according to Hugosson method a piece of each stone was added to BHI (Brain heart infusion) broth and another piece was added to Thioglycolate medium. The medium was incubated for $48 \mathrm{~h}$ at $37^{\circ} \mathrm{C}$ and then applied for presence of microorganisms. Different culture media such as Baird parker, DNase, MSA (Manitol salt agar), etc. were applied for discrimination of different kinds of bacteria.
3.4. Determination of Fimh Gene Frequency in E. coli Separated From Kidney Stones

Since the number of separated E. coli bacteria from previous steps was small (found in five samples), 42 further samples were gathered from UTI patients and seven samples were diagnosed to have kidney stones containing E. coli. Genomic DNA of E. coli bacteria of these 12 samples was extracted using MBST kit (Roshd, Iran). The fimH gene was amplified by PCR using following primers: Forward (5'-TCCCGTTACAGGTCAGAGC-3'), Reverse (5'-GTGCAGGTTTTAGCTTCAGG-3') [12]. The PCR program was as follow: (pre-denaturation at $95^{\circ} \mathrm{C}$ for $5 \mathrm{~min}$, followed by 25 cycles at $95^{\circ} \mathrm{C}$ for $1 \mathrm{~min}, 55^{\circ} \mathrm{C}$ for 30 seconds, $72^{\circ} \mathrm{C}$ for 1 $\mathrm{min}$ and a final-extension at $72^{\circ} \mathrm{C}$ for $5 \mathrm{~min}$ ). The PCR product was run on a $1 \%$ agarose gel and the bands were visualized using transilluminator.

\subsection{Fimh Protein Extraction From E. coli Bacteria}

In order to extract FimH protein, TES [Tris-HCl, ethylenediaminetetraacetic acid (EDTA) and sucrose] solution (Sigma, US) was used and some distilled water was added gradually to find the optimum condition in which only the periplasmic proteins are released without cell lysis. Initially $1.5 \mathrm{~mL}$ of bacterial culture was centrifuged at $4^{\circ} \mathrm{C} 5000 \mathrm{~g}$ for $5 \mathrm{~min}$. The supernatant was removed completely and the pellet was dissolved at TES solution and placed on ice and slightly shook for $20 \mathrm{~min}$. After adding $1.5 \mathrm{~mL}$ distilled water the shaking on ice was continued to 35 min more. After osmotic shock, in order to isolate periplasmic proteins, cell samples were centrifuged at $4^{\circ} \mathrm{C}, 14000 \mathrm{~g}$ for $20 \mathrm{~min}$. The supernatant contained periplasmic proteins and the pellet contained spheroplastic proteins. Extracted proteins were confirmed using sodium dodecyl sulfate polyacrylamide gel electrophoresis (SDS-PAGE).

\subsection{Statistical Analysis}

Data were analyzed using Graphpad prism 6.01 and also SPSS-16 programs. Data were compared with each other by student t-test. P values $\leq 0.05$ were considered significant.

\section{Results}

\subsection{Frequency of Kidney Stones:}

From 40 kidney stones samples, 12 samples (30\%) separated from women and 28 samples (70\%) belonged to men. According to the hospital documents, 55\% of studied samples were from tropical regions (south and north of Iran), $30 \%$ were from moderate regions (the center of Iran) and the remained ones were from other places. 


\subsection{Kidney Stone Composition and Bacteria}

In order to define the structure and identity of separated kidney stone, the samples composition and bacterial content were obtained. Table 1 summarizes the composition of kidney stones samples. As it shows, the most prevalence of stones belongs to calcium oxalate (whewillite) stones. The most frequent bacterium in kidney stones was E. coli (29.41\%). The percent of different kinds of bacteria in the samples is summarized in table 2.

In the present study, no microorganism was observed in 23 of 40 kidney stones culture. The frequency of isolated microorganisms in kidney stones cultures was as follow: E. coli (29.41\%), Staphylococcus spp. (17.64\%), Klebsiella spp. (11.76\%) and Proteus spp. (5.8\%). Although E. coli produces a little amount of urease, it was seen in $29.41 \%$ of the patients, raising a question whether urease-producer bacteria are necessary for kidney stones formation or not. To answer to this question, it could be proposed that we might be unable to recognize some microorganism such as mycoplasma (Ureaplasma urealyticum, Bacteroides, etc.) with common experimental methods. Another possibility is that urease-producer microorganisms initially appear as transient infection and disappeared after kidney stone formation. It is also possible that kidney stones can be formed in presence of non-urease-producer bacteria.

Table 1. The Prevalence of Different Kidney Stones

\begin{tabular}{lc}
\hline Kidney stone type & Prevalence (\%) \\
\hline Whewillite & 63.40 \\
\hline Brushite & 15.07 \\
\hline Apatite & 3.62 \\
\hline Struvite & 1.25 \\
\hline Uric acid & 9.57 \\
\hline Cystine & 0.75 \\
\hline
\end{tabular}

\subsection{Frequency Of Fimh Gene And Fimh Protein}

From 12 E. coli samples, eight samples have fimH gene which was amplified by PCR and four samples were negative for this gene. FimH protein was obtained from six samples ( $\mathrm{a} \sim 32 \mathrm{kDa}$ band on SDS-PAGE) and other six samples did not have the FimH protein band (the SDS-PAGE result of some samples is shown in Figure 2).

\section{Discussion}

From 40 studied kidney stones samples, 28 samples (70\%) were separated from male patients and 12 samples
Table 2. The Prevalence of Different Bacteria Isolated From Kidney Stone Samples

\begin{tabular}{lc}
\hline Bacteria & Prevalence(\%) \\
\hline E.coli & 29.41 \\
\hline Staphylococcus & 17.64 \\
\hline Klebsiella & 11.76 \\
\hline Entrobacter & 5.88 \\
\hline Citrobacter & 5.88 \\
\hline Proteus & 5.88 \\
\hline Ervinia & 5.88 \\
\hline Bacillus & 5.88 \\
\hline Klebsiella-Bacillus & 11.76 \\
\hline Not-detected & 0.03 \\
\hline
\end{tabular}

(30\%) were separated from females. It shows that male patients are significantly more prone to kidney stones formation in comparison with females. The main calcium stone was calcium oxalate stone with a frequency of $63.4 \%$. The frequency os struvite stone was $1.25 \%$. The lowest prevalence of stone was cystine. All samples were 82 (40 samples of kidney stones and 42 samples of UTI). E. coli was found in 12 samples of all patients. The frequency of fimH gene in isolated E. coli was $57.14 \%$ by PCR. Protein extraction was from separated E. coli bacteria. The FimH protein was seen only in $50 \%$ of our samples by SDS-PAGE.

It is noteworthy that similar to our study, Stamatelou et al. reported a prevalence of $6 \%$ and $12 \%$ of kidney stones for female and male subjects, respectively [14]. Rivera declared that the most prevalence of kidney stone is seen where the temperature and moisture are high [15]. Similarly, in the present study, 30\% of studied subjects were from tropical regions (south and north of Iran), 30\% were from moderate regions (the center of Iran), and the remained ones were from other places. These results suggest that the formation of kidney stone may increase in tropical regions. Kramer et al. declared that calcium oxalate stones formed by E. coli cover the most frequent quota of urinary stones in the western world. They showed that the urinary stones may be initially formed and then be infected with bacteria. They also announced that the bacteria which are the main reason of chronic urinary tract infections and exist inside the urinary tract (urea-splitting bacteria) may cause stone formation. Although the origin of struvite stones may be de novo, often urea-splitting bacteria infect pre-existing stones. There is evidence showing that UTI caused by ureasplitting bacteria are not exclusively correlated with the struvite stones formation [16]. The frequency of struvite stone was $1.25 \%$ in our study. Ansari et al. studied on 1050 kidney stone samples. In their study, the prevalence of cal- 


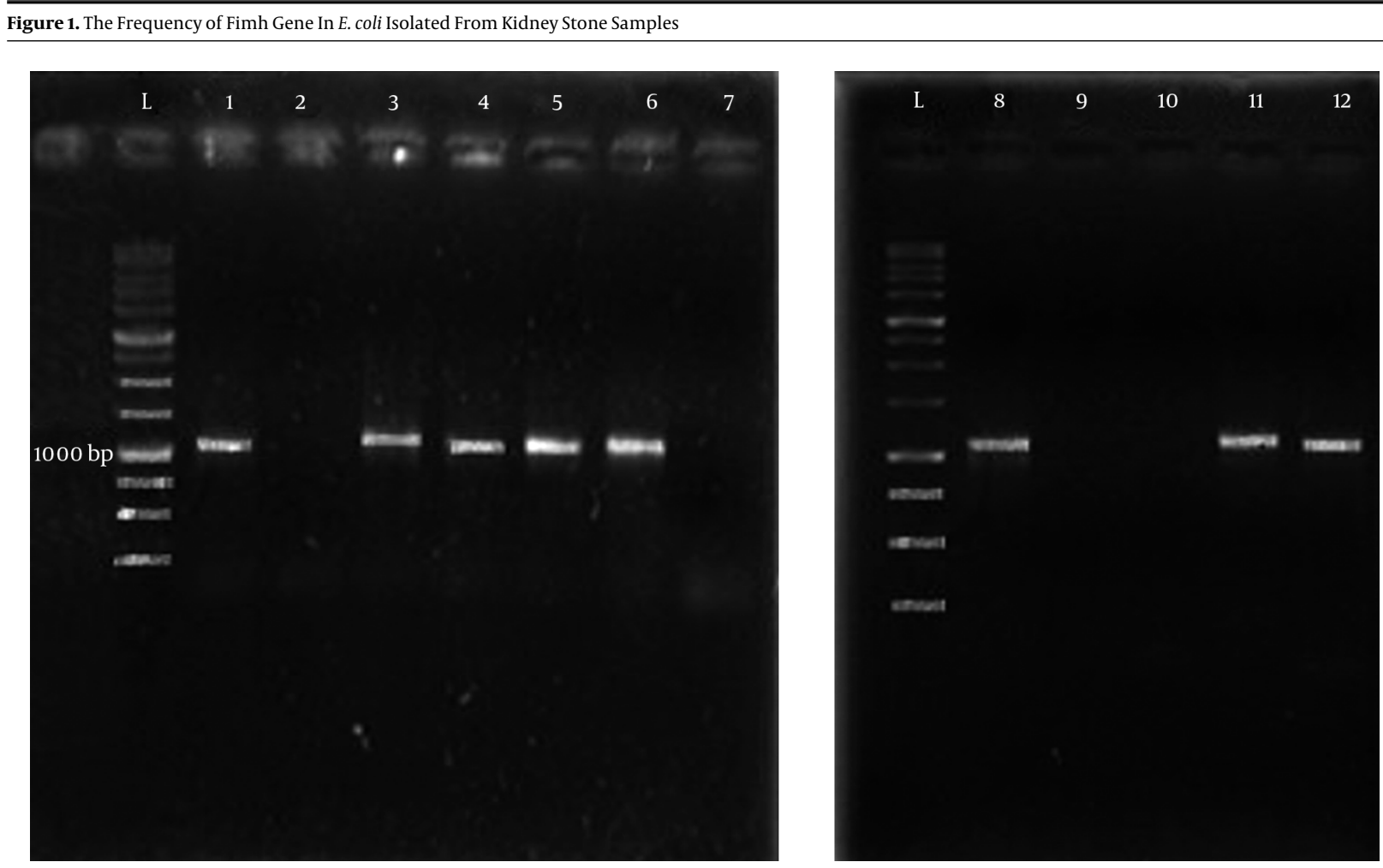

The presence of fimH gene (1047 bp) is seen in samples 1, 3, 4, 5, 6, 8, 11 and 12. Lane L indicates the DNA ladder

Figure 2. The Frequency of Fimh Protein In E. coli Isolated From Kidney Stone Samples

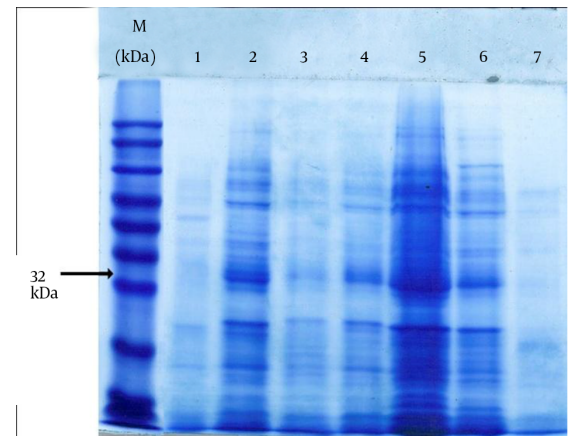

Only seven samples (out of 12 samples) have been shown here. The presence of FimH protein $(32 \mathrm{kDa})$ is seen in samples $2,3,4,5$ and 6 . Lane $\mathrm{Mw}$ indicates the protein ladder

cium oxalate, struvite, apatite and uric acid stones were 93.04\%, $1.92 \%, 1.48 \%$, and $0.95 \%$ respectively and $2.96 \%$ of samples were consisted of a mixture of different stones [17]. In Akagashi et al. study, struvite and calcium oxalate stones covered $32.1 \%$ and $22.2 \%$ of kidney stones samples [18]. The frequency of struvite stones was determined 15
- 20\% in Griffith study [19]. Gomez-Nunez et al. showed a frequency of $2 \%$ for struvite stones and declared that nowadays the frequency of this stone is decreasing with unknown reasons [11]. This information demonstrates a large difference of struvite stones prevalence. As GomezNunez et al. suggested, this inconsistency may refer to differences in ethics, genetics, geographic location, nutrition, lifestyle and metabolism [11]. In our study uric acid stones covered $9.75 \%$ of kidney stones. In a study by Parmar, $5-10 \%$ of studied kidney stones were uric acid stones [20]. The prevalence of uric acid stone was reported $10 \%$ in Coe et al. study [21]. Our results are consistent with Parmar and Coe et al. results. Tavichakorntrakool et al. obtained a prevalence of $14 \%$ for uric acid stones which is inconsistent with our study [22]. This inconsistency may refer to nutrition, climate, job, etc. In the present study, calcium stones covered $82.09 \%$ of all stones. The main calcium stone was calcium oxalate stone with a frequency of $63.4 \%$. A frequency of $75-80 \%$ was determined for calcium stones in Pak study and the main calcium stone of their study was calcium oxalate [23]. Similarly, Coe et al. report a prevalence of $80 \%$ for calcium stones with predominant frequency of calcium oxalate stones [21]. Calcium stone prevalence was determined $77 \%$ in Tavichakorntrakool et 
al. study, which among them calcium oxalate covered 51\% of cases [22].

Abrahams and Stoller showed that $67 \%$ of calcium oxalate stones contain phosphate in their center [24]. However this frequency was reported $90 \%$ in Grases et al. study [25]. Consistent to mentioned researches, our results also showed a high prevalence for calcium stones with a predominant frequency for calcium oxalate stones. Also $18.92 \%$ of our calcium stones were pure calcium oxalate and in $63.7 \%$ of calcium stones phosphate was observed. These results were also consistent with previous studies. The prevalence of cystine stones was determined $0.75 \%$ in our study. This prevalence was reported $1.4 \%$ by Ciftcioglu et al. [26]. Although our result is not consistent with Ciftcioglu et al. study, as declared by Parks and Pearle, the cystine stones are scarce and they are not clinically important [27]. In this study, 40 kidney stones in addition to 42 UTI patients were studied. Stones were also found in seven patients of UTI subjects. E. coli was found in 12 samples of all patients.

The frequency of fimH gene in isolated E. coli was 57.14\%. Usein et al. studied on $78 \mathrm{E}$. coli isolated from urinary tract infection [28]. The frequency of fimH gene in their study was $86 \%$. This frequency was determined $83 \%$ in Kaczmarek et al. study [29]. Khorshidi et al. studied on 313 child fecal samples and reported the prevalence of $98 \%$ for fimH gene [30]. In other researches by Karimian et al. on 123 E. coli samples [31] and Moreno et al. on 21 E. coli samples [32] this frequency was reported $79.67 \%$ and $95 \%$ respectively.

In contrast with mentioned studies, the fimH gene frequency in Lichodziejewska et al. [33], Pere et al. [34], and Kisielius et al. [35] studies were 38\%, 45\% and 76\% respectively. This large discrepancy in previous studies may refer to the different environments because it has been shown that the fimH gene prevalence is affected by environmental factors [36]. Furthermore this discrepancy may be occurred because of the phase changes of bacteria as a direct correlation exists between the fimH gene frequency and subculturing of bacteria. In the initial studies on fimH, the mannose-sensitive hemaglutinin function was only observed in two of 24 urine samples but it increased up to 11 samples after subculturing of the samples [37]. These studies suggest that fimH gene frequency strictly depends on the study conditions. Although FimH protein was seen only in $50 \%$ of our samples (and it could be due to weakness of the extraction process), it seems that fimH gene may have a role in kidney stone formation or progression because a significant correlation was seen between fimH gene and the formation of kidney stone. It should be noted that the kidney stones formation is not necessarily dependent on fimH gene and other factors such as pap, cnf-1, etc. may play a role in kidney stones formation. Our data indi- cated that kidney stone disease and UTIs are not only associated with struvite stones and almost all chemical types of kidney stones may involve in UTI and kidney stone formation. We also realized that although E. coli is a non-urea splitting bacteria, it is the most causative microorganism found in urine and stone. Finally we recognized that fimH gene is seen in the majority of kidney stone samples so it may have a role in forming of kidney stone, although it should be more clarified in future studies.

\section{Acknowledgments}

This study is a part of MSc thesis (thesis No. 15730507902009) in Islamic Azad University, Tehran North Branch by Ali Shojaeian.

\section{Footnotes}

Authors' Contribution: Ali Shojaeian and Jamileh Noroozi conceived idea of the research. All authors contribute in experiment performance and have read and corrected the manuscript.

Conflict of Interest: The authors declare no conflict of interest.

Funding/Support: This work was financially supported by Islamic Azad University, Tehran North Branch.

\section{References}

1. Yoshida O, Terai A, Ohkawa T, Okada Y. National trend of the incidence of urolithiasis in Japan from 1965 to 1995. Kidney Int. 1999;56(5):1899904. doi: 10.1046/j.1523-1755.1999.00754.x. [PubMed:10571800].

2. Verkoelen CF, van der Boom BG, Schroder FH, Romijn JC. Cell cultures and nephrolithiasis. World J Urol. 1997;15(4):229-35. [PubMed: 9280051].

3. Mandel N. Mechanism of stone formation. Semin Nephrol. 1996;16(5):364-74. [PubMed: 8890393].

4. Ma W, Guttman DS. Evolution of prokaryotic and eukaryotic virulence effectors. Curr Opin Plant Biol. 2008;11(4):412-9. doi: 10.1016/j.pbi.2008.05.001. [PubMed: 18585954].

5. Oelschlaeger TA, Dobrindt U, Hacker J. Virulence factors of uropathogens. Curr Opin Urol. 2002;12(1):33-8. [PubMed: 11753131].

6. Hommais F, Gouriou S, Amorin C, Bui H, Rahimy MC, Picard B, et al. The FimH A27V mutation is pathoadaptive for urovirulence in Escherichia coli B2 phylogenetic group isolates. Infect Immun. 2003;71(6):3619-22. [PubMed: 12761149].

7. Connell H, Poulsen LK, Klemm P. Expression of type 1 and $P$ fimbriae in situ and localisation of a uropathogenic Escherichia coli strain in the murine bladder and kidney. Int J Med Microbiol. 2000;290(7):587-97. doi: 10.1016/S1438-4221(00)80006-5. [PubMed: 11200540].

8. Schembri MA, Christiansen G, Klemm P. FimH-mediated autoaggregation of Escherichia coli. Mol Microbiol. 2001;41(6):1419-30. [PubMed: 11580845].

9. Zanetti G, Paparella S, Trinchieri A, Prezioso D, Rocco F, Naber KG. Infections and urolithiasis: current clinical evidence in prophylaxis and antibiotic therapy. Arch Ital Urol Androl. 2008;80(1):5-12. [PubMed: 18533618]. 
10. Qaader DS, Yousif SY, Mahdi LK. Prevalence and etiology of urinary stones in hospitalized patients in Baghdad. East Mediterr Health J. 2006;12(6):853-61. [PubMed: 17333833].

11. Gomez-Nunez JC, Alvarez UM, Fernandez F. Infected urinary stones, endotoxins and urosepsis. Croatia: INTECH Open Access Press; 2011. pp. 183-98.

12. Fallah-Merhrabadi J, Ghoraba H, Imani Fooladi AA, Rohaninejad $\mathrm{H}$. Comparing of fimH gene variation in normal flora and uropathogenic Escherichia coli. Trauma Mon. 2010;15(2):65-9.

13. Miano R, Germani S, Vespasiani G. Stones and urinary tract infections. Urol Int. 2007;79 Suppl 1:32-6. doi:10.1159/000104439. [PubMed: 17726350].

14. Stamatelou KK, Francis ME, Jones CA, Nyberg LM, Curhan GC. Time trends in reported prevalence of kidney stones in the United States: 1976-1994. Kidney Int. 2003;63(5):1817-23. doi: 10.1046/j.15231755.2003.00917.x. [PubMed: 12675858].

15. Rivera JV. Urinary calculi in Puerto Rico: II. Seasonal incidence. Bol Asoc Med P R. 1973;65(2):28-31. [PubMed: 4532561].

16. Kramer G, Klingler HC, Steiner GE. Role of bacteria in the development of kidney stones. Curr Opin Urol. 2000;10(1):35-8. [PubMed:10650513].

17. Ansari MS, Gupta NP, Hemal AK, Dogra PN, Seth A, Aron M, et al. Spectrum of stone composition: structural analysis of 1050 upper urinary tract calculi from northern India. Int J Urol. 2005;12(1):12-6. doi: 10.1111/j.1442-2042.2004.00990.x. [PubMed: 15661049].

18. Akagashi K, Tanda H, Kato S, Ohnishi S, Nakajima H, Nanbu A, et al. Characteristics of patients with staghorn calculi in our experience. Int J Urol. 2004;11(5):276-81. doi: 10.1111/j.1442-2042.2004.00800.x. [PubMed: 15147542].

19. Griffith DP. Struvite stones. Kidney Int. 1978;13(5):372-82. [PubMed: 351265].

20. Parmar MS. Kidney stones. BMJ. 2004;328(7453):1420-4. doi: 10.1136/bmj.328.7453.1420. [PubMed: 15191979].

21. Coe FL, Evan A, Worcester E. Kidney stone disease. J Clin Invest. 2005;115(10):2598-608. doi: 10.1172/JCI26662. [PubMed:16200192].

22. Tavichakorntrakool R, Prasongwattana V, Sungkeeree S, Saisud P, Sribenjalux P, Pimratana C, et al. Extensive characterizations of bacteria isolated from catheterized urine and stone matrices in patients with nephrolithiasis. Nephrol Dial Transplant. 2012;27(11):4125-30. doi: 10.1093/ndt/gfs057. [PubMed: 22461670].

23. Pak CY. Etiology and treatment of urolithiasis. Am J Kidney Dis. 1991;18(6):624-37. [PubMed: 1962646].

24. Abrahams HM, Stoller ML. Infection and urinary stones. Curr Opin Urol. 2003;13(1):63-7. doi: 10.1097/01.mou.0000049383.71470.c4. [PubMed: 12490818].

25. Grases F, March JG, Conte A, Costa-Bauza A. New aspects on the compo- sition, structure and origin of calcium oxalate monohydrate calculi. Eur Urol. 1993;24(3):381-6. [PubMed: 8262107].

26. Ciftcioglu N, Bjorklund M, Kuorikoski K, Bergstrom K, Kajander EO Nanobacteria: an infectious cause for kidney stone formation. Kidney Int. 1999;56(5):1893-8. doi: 10.1046/j.1523-1755.1999.00755.x. [PubMed: 10571799].

27. Park S, Pearle MS. Pathophysiology and management of calcium stones. Urol Clin North Am. 2007;34(3):323-34. doi: 10.1016/j.ucl.2007.04.009. [PubMed: 17678983].

28. Usein CR, Damian M, Tatu-Chitoiu D, Capusa C, Fagaras R, Tudorache $\mathrm{D}$, et al. Prevalence of virulence genes in Escherichia coli strains isolated from Romanian adult urinary tract infection cases. J Cell Mol Med. 2001;5(3):303-10. [PubMed: 12067489].

29. Kaczmarek A, Budzynska A, Gospodarek E. Prevalence of genes en coding virulence factors among Escherichia coli with $\mathrm{K} 1$ antigen and non-K1 E. coli strains. J Med Microbiol. 2012;61(Pt 10):1360-5. doi: 10.1099/jmm.0.044263-0. [PubMed: 22745135].

30. Khorshidi A, Motallebi M, Rohani M, Piroozmand A. Characterization of virulence genes in typical and atypical enteropathogenic Escherichia coli. Sci Res Essays. 2011;6(31):6600-5.

31. Karimian A, Momtaz H, Madani M. Detection of uropathogenic Escherichia coli virulence factors in patients with urinary tract infections in Iran. Afri J Mic Res. 2012;6(39):6811-6.

32. Moreno E, Andreu A, Perez T, Sabate M, Johnson JR, Prats G. Relationship between Escherichia coli strains causing urinary tract infection in women and the dominant faecal flora of the same hosts. Epidemiol Infect. 2006;134(5):1015-23. doi: 10.1017/S0950268806005917. [PubMed: 16438745].

33. Lichodziejewska M, Topley N, Steadman R, Mackenzie RK, Jones KV, Williams JD. Variable expression of P fimbriae in Escherichia coli urinary tract infection. Lancet. 1989;1(8652):1414-8. [PubMed: 2567430].

34. Pere A, Nowicki B, Saxen H, Siitonen A, Korhonen TK. Expression of P, type-1, and type-1C fimbriae of Escherichia coli in the urine of patients with acute urinary tract infection. J Infect Dis. 1987;156(4):56774. [PubMed: 2887621].

35. Kisielius PV, Schwan WR, Amundsen SK, Duncan JL, Schaeffer AJ. In vivo expression and variation of Escherichia coli type 1 and $P$ pili in the urine of adults with acute urinary tract infections. Infect Immun. 1989;57(6):1656-62. [PubMed: 2566580].

36. Brinton CJ. Non-flagellar appendages of bacteria. Nature 1959;183(4664):782-6. [PubMed: 13644195].

37. Ofek I, Goldhar J, Eshdat Y, Sharon N. The importance of mannose specific adhesins (lectins) in infections caused by Escherichia coli. Scand J Infect Dis Suppl. 1982;33:61-7. [PubMed: 6753135]. 